\title{
THE MASKS OF ORTHIA: FORM, FUNCTION AND THE ORIGINS OF THEATRE
}

\author{
by Jonah Lloyd Rosenberg
}

\begin{abstract}
The British School excavations in Laconia from 1905 to 1910 unearthed terracotta masks from the sanctuary of Artemis Orthia, just east of Sparta, right on the Eurotas river. Buried in two pits adjacent to the archaic temple, the masks were made between c. 615 and c.45O BCE. Description and analysis of the material and technique of the masks reveal their diverse character and the impracticalities of their being worn. The masks' function is related to the presence of linen or wood originals that the terracotta versions reproduced, though not uniformly. Difficulty in explaining the (original) masks' use is predicated on vague approximations of the nature of Orthia's origins and cult. The linguistic clusters proposed by the excavators as early as 1906 as descriptors of the masks or their use are scrutinised for possible illumination of the (original) masks' use; the burial of the masks some centuries before the descriptions of Pollux, Hesychius and Pausanias begs the question of their applicability to the excavated masks. On the basis of theories of masking from Classics as well as from fapanese Noh theatre and neuroscience, the 'grotesques' and 'caricatures' proposed by the excavators are recast as comic and satiric figures. Like Aristotle's pre-urban drama, the 'Orthian drama' does not correspond to a single theatrical genre, but contains risible figures whose facial expressions are naturalistic and often negative (pain, worry). Given Aristotle's firm assertion that the roots of Greek theatre are Dorian, and the uniqueness of the Orthia material, it is proposed that these masks point us towards the origins of theatre.
\end{abstract}

\section{INTRODUCTION}

The British School's excavations at the sanctuary of Orthia at Sparta, inaugurated in 1906 under Bosanquet, revealed an uncommon trove - actually two discrete and intentional deposits either side of the temple - of terracotta masks, dating from the end of the seventh century through the fifth. Many thousands of fragments and hundreds of more or less complete masks were found, and are now kept principally at the Sparta Museum, at the National Archaeological Museum in Athens and at the British Museum. Their initial publication, in this journal (Bosanquet I906), connected them with literary descriptions, a mode that persists. The last major study of the masks, Carter's I987 article (Carter I987), concerns itself with the masks' origins, looking especially towards Phoenician sources ( $c f$. Di Clemente 2008). Importantly, Carter calls into question some of the equations of masks with literary accounts of rituals in honour of Orthia that Dickins, who was responsible for their treatment in the excavation's final publication (Dawkins 1929), makes.

Scholarly treatments of the masks seldom consider all of their types (Dawkins I929 settles on seven). It is clear that the masks were commingled in the deposits, and there would have to be a very good reason indeed - and I know of none that has been advanced - to suppose that the masks do not correspond to a single phenomenon. This provoked the study below: there is no satisfactory account of the masks because scholars tend to focus on the most unusual examples, especially the 'grotesques', and either to generalise from them or to ignore the others. With this in mind, my first concern is to describe more accurately the masks' forms. Then I shall analyse their function, and finally propose some conclusions.

\section{FORM}

The scale drawings in Dawkins 1929 and personal observation demonstrate that most of the masks are rather smaller than life-size. The excavators found some below but many more above the 'sand layer' that was made in preparation for the new temple of Orthia in a sanctuary of the goddess on 
the western bank of the river Eurotas, just east-south-east of Sparta. ${ }^{\mathrm{I}}$ This layer is dated by Dawkins et al. to $600 \mathrm{BCE}^{2}$ by Boardman in this journal to 570/560 (Boardman 1963, 4) and (tentatively) by Catling to $c .590$ (Catling 1977, 24-42). Since masks emerging from the same mould have been found either side of the sand (Dawkins 1929, I64), the building of the temple did not particularly alter their forms. Because there are few comparanda, it is difficult to parse their style for indications of date, especially as there must be accommodation for some sort of use-life before inhumation. The earliest might therefore be dated to the late seventh century, though Dickins compares their style to Laconian III, which begins (by Boardman's reckoning) c.580. A very precise date may not be plausible, but $c .615-575$ for the earliest masks is reasonable. The series continues perhaps to the end of the fifth century, becoming truly miniature.

Dickins's seven types are fairly straightforward: old women, youths, warriors, portraits, satyrs, gorgons and caricatures (Dawkins 1929, I66-9). Though some of the names are difficult to accept, the division is clear enough. Some, in the service of their arguments, have sought to collapse or unite some types, as Carter (1987, 35), who would recognise only 'heroes' and 'furrowed grotesques', to include satyrs and gorgoneia. Dickins's satyrs, portraits and gorgoneia cease by the end of the sixth century, ${ }^{3}$ leaving a fourfold division, though many of the types bear subdivision.

The masks are made of local clay like that used for vases, and are unpainted about two-thirds of the time; Dickins writes that most were mould-made (Dawkins I929, I69), though, intriguingly, Bosanquet (1906, 338 - by which point some but not all masks had been excavated) suggests that most were handmade. This can in fact have little effect on the final form, as there was a great deal of hand-working even on mould-made pieces, such that no two are identical. The fabric is quite friable, and generally a pinkish grey, though it can appear orange or yellow. Dickins attributes variation to firing (Dawkins 1929, I69) but does not acknowledge that there are in fact several different fabrics used, ranging in colour but also in coarseness, inclusions and thickness. This seems to indicate several workshops.

So much for material; a wide variety of techniques was used in the forming of the masks. One of the best-illustrated and best-preserved mask fragments (Fig. I), now in the British Museum, 4 demonstrates several. The mask was worked particularly heavily with tools, as opposed to the softer modelling executed by fingers visible in other masks. This is evident on the inside of the mask (Fig. 2), where small gouges with rough edges are the imprint of the process of hollowing the shape. While the fabric is not the thinnest of surviving masks', it is not as coarse as others'. The hole in the chin is a sign of this: it removes an otherwise solid mass of clay that would be prone to crack or explode in the kiln because of the difference in water content and temperature between it and the mask's thinner portions. The nostrils (concavities rather than holes) serve the same purpose. The hole at the edge of the rim, however, must be for fastening. The hole is not positioned for the mask to sit flush like a protome, but is at an angle, suggesting either suspension or fastening to a rounded object. Some do have a flat rim but are unpierced perhaps for display on a horizontal surface.

Turning to the exterior, the 'wrinkles' stand fully outside the smooth contour of the rest of the mask, which indicates two distinct processes: building them up past the surface and then excavating furrows. As is clear in the wrinkles furthest from the mouth and higher up the face, the tool used was flat or $\mathrm{V}$-shaped, creating a straight slope rather than a curve. The sharp edges are visible too at the lips, with the ninety-degree ledge of the lower lip and the clean ridge of the upper lip. The lips are remarkably graphic; the corner of the mouth does not fade into the naso-labial fold but stands distinct. Perhaps this is an indication of paint on the lips; traces of black and yellow slip elsewhere on the mask point to polychromy.

Coordinates: $37^{\circ} 4.998^{\prime} \mathrm{N}, 22^{\circ} 26.126^{\prime} \mathrm{E}$. The first stone temple was built $c .725$ BCE.

Dawkins I929, I7; cf. the diagram in Dawkins et al. I906/7, 6I: the sand level is put around 550 BCE.

Dawkins I929, I66 observes the shift; absolute chronology is based on Boardman I963.

It should be noted that a box of material, including many mask fragments, was found by the staff of the British

Museum in I998 and given accession numbers of I999.II-I.X; the box was apparently given to the museum in I923 along with the other material from the British School excavations but not sorted or catalogued. 




Fig. I. Terracotta mask fragment, chin to cheek, Dickins type ii.b (caricatures of 'old women'). Found near the archaic temple, Sanctuary of Artemis Orthia in Laconia. Max. height II.5 cm; c.600 BCE. BM I923.2-I2.249. Photograph: (C) Trustees of the British Museum.

By way of contrast, consider the upper part of a second mask (Fig. 3) composed of two joined fragments. The hair is parted in the middle, and there are five surviving holes in the forehead (for a wreath? radiate crown? fillet? individual tresses?). At its thickest $2.5 \mathrm{~cm} / \mathrm{I}$ in., this mask is in every way coarser than the previous one. The fabric is more orange and contains many more inclusions, though most are small. At a weight of $316 \mathrm{~g} / \mathrm{II} . \mathrm{I}$ oz - the complete mask perhaps triple that at just under $\mathrm{I} \mathrm{kg} / 2 \mathrm{lb}$ - this would have been difficult to wear, even though its size would allow it to fit over a very small face (in turn making the weight even more difficult to support). The technique of execution also differs from that used on Fig. I; a broad, flat tool has been used to smooth the inside of the mask, leaving very clear marks (Fig. 4). The furrows of the outside are simply dug into the surface, allowed by the exceptional thickness, by a tool with



Fig. 2. Interior view. Photograph: author; (C) Trustees of the British Museum. 




Fig. 3. Terracotta mask fragment, hair and brow. Found near the archaic temple, sanctuary of Artemis Orthia in Laconia. Max length $15 \mathrm{~cm}$; c.575 BCE. BM 1923.2-I2.254. Photograph: author; (C) Trustees of the British Museum.

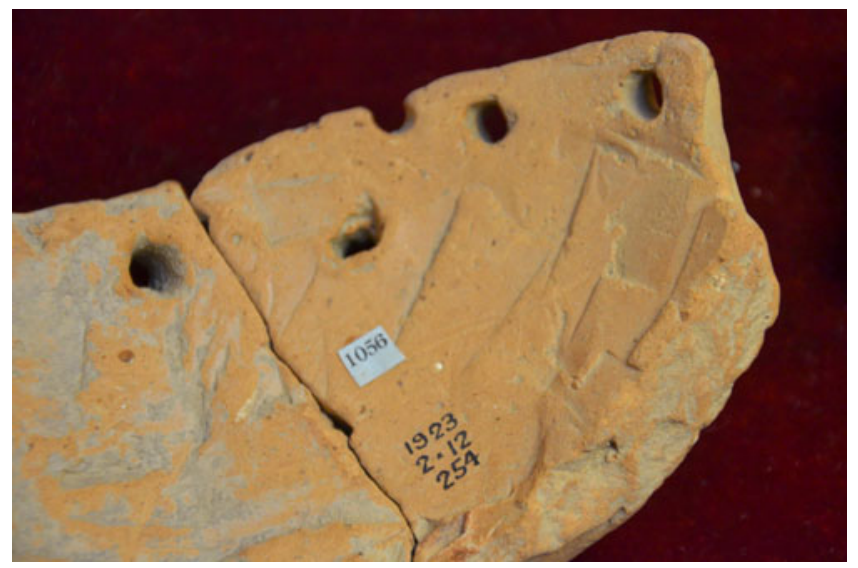

Fig. 4. Interior view. Photograph: author; (C) Trustees of the British Museum.

a rounded-v profile - others (e.g. BM I999.II-I.II5) have furrows with U-shaped profiles, perhaps made by fingernails.

Features could also be indicated by means of added clay, more or less smoothed to appear integrated or to stand proud (as in Fig. I). This ridge on the right cheek is difficult to interpret; perhaps it is meant purely decoratively, rather than as a referent to an anatomical feature, though it could be a tress of hair. This technique in particular raises issues of the connection of the surviving votives with the masks for which they stand in. If, as nearly every scholar who has written on the masks accepts, the masks are a durable replacement for 'original' masks made of linen or wood (vel sim.), we must concede that the connection is not perfectly straightforward; for example, working upwards from the surface via addition is not plausible (especially in wood). To use the terms of Gombrich, because of the variation of the output when the ephemeral medium is translated into the durable medium, we cannot distinguish the permanent (linen/ wood) components $(p)$ from the mobile (variations in the execution of the ceramic masks) components $(m)$, since we see only their product $(p m)$ (Gombrich 1982, I26-9).

Dickins sees no influence of woodcarving in the technique of the masks, 5 though how precisely this would manifest is hard to say. Probably the moulds, if used, were themselves wooden, as wood

5 Dawkins I929, I7I; cf. Bosanquet I906, 340: the earliest mask, a gorgon, 'may perhaps reproduce the angular lines of a clumsy wooden original'. 




Fig. 5. Terracotta protome, probably Bes, from Amathus (Cyprus), site E, tomb 83. Height: I7.5 cm; 600-500 BCE. BM I894.II-I.I89. Photograph: (C) Trustees of the British Museum.

draws moisture from clay, which eases its removal. This would account for no moulds having been found. The thick stacks of parallel lines that have been called wrinkles are very reminiscent of the graining of wood, which perhaps was their origin; compare the sixth-century Cypriot mask of a grimacing Bes (Fig. 5), whose 'wrinkles' are much more clearly wooden; the characterisation of Bes as facially expressive is long-standing in his iconography. What is remarkable about the Orthia masks is that some - one might be permitted to say the finest, e.g. that illustrated in Fig. I - have wrinkles that correspond to a deep anatomical understanding of the facial muscles' motion. This motion is perhaps the key to better understanding the masks' function.

\section{FUNCTION}

The use of the ceramic masks is not really at issue: they are dedications that were displayed in the temple or its temenos and eventually were cleared when they became too numerous or were no longer relevant to the cult. ${ }^{6}$ Most of the ceramic masks are quite simply too small to be worn; moreover, wearing a clay mask is very restrictive, and is not practicable in the execution of the dances that were doubtless taking place. 7 Since the masks were buried together, it makes sense to consider them to have had a single function, so if most could not be worn, the whole lot was not intended for use; indeed, few believe that these masks were ever worn for performance or

\footnotetext{
6 Nilsson, I955 I.I62 is quite plain on the subject.

$7 \quad C f$. the clay mask of Anubis now in Hildesheim (Pelizäus-Museum 1575) and the illustration of its use in Leprohon 2007, 269-70: the mask-wearer is steered by an unmasked aid. Plutarch, projecting into deep antiquity, could write of Helen (Theseus, 3I.2) that she was dancing at the sanctuary of (Artemis) Orthia when she was abducted.
} 
indeed any purpose at all. What has fascinated scholars and spurred their theories is the recapture and study of a vanished class of object that stands in some relation to those that survive, and what the use of those masks might have been.

The first theory, advanced by Bosanquet in this journal, and accepted by nearly all scholars, was that these masks were replicas of those used in some sort of ritual behaviour as described in Pollux and Hesychius (Bosanquet 1906, 338); Dickins, in the final publication of 1929, accepts and pursues this connexion. Pollux, writing of Spartan dances in a larger section on dance, names


out by women for Artemis and Apollo. ${ }^{8}$ There is no mention of masks. Hesychius has several similar headwords: $\beta \rho v \alpha \lambda i \kappa \tau \alpha 1,{ }^{9} \beta \rho v \delta \alpha \lambda i \chi \alpha \alpha, \beta \rho v \lambda \lambda \imath \chi 1 \sigma \tau \alpha i$ (Lexicon, s.vv.), but to his or his source's knowledge, the masks are worn by men (or men and women, though this is ritually unlikely) and specifically impersonate women. ${ }^{\text {I }}$ Dickins tries to defend the discrepancy in the mask-wearers' sex as reported by Pollux and Hesychius, but it is not at all clear that the two are describing the same phenomenon.

Pausanias discusses Spartan Orthia, and disassociates her, notably, from Artemis - unlike Pollux. ${ }^{\text {II }} \mathrm{He}$ does not mention masks at all, but instead the whipping of boys at the altar, of which much has been made by Calame and by Vernant (1984, 26-7). ${ }^{\text {I2 }}$ Which types were worn by ephebes donning masks as part of the embrace of humiliation? Parker suggests that they would don sometimes a shameful (old woman, grotesque, caricature, satyr, gorgon[?]), sometimes a heroic mask (warrior, portrait[?]; Parker 1989, I52). In this case, the Spartiate absorbs the helot and forms a complete set, self and other married with a mask. ${ }^{13}$ This certainly acts as a type of theatre, if not in a form that we would easily recognise.

Yet Bosanquet makes another suggestion in his 1906 publication, one that has not gained so much traction among later scholars: that these masks (i.e. the 'originals') were used more lightheartedly, ranging from rustic fertility rites to outright comedy, of which there is a description in Athenaeus: ${ }^{\mathrm{I}}$







Among the Spartans there was a certain ancient type of comic pastime, as Sosibios says ... the participants in such a pastime are called image-users by the Spartans, while others call them prop-makers (mask-users?) and imitators.

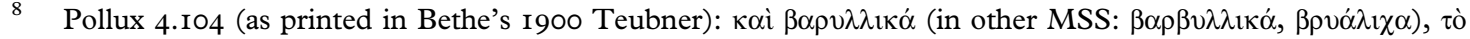




text is corrupt.


behind a mask'. Bergk offers a different $v . l$. in his edition.


ugly feminine masks and singing hymns'.

II Pausanias 3.I6.9-II. Cf. Kowalzig's article on Orthia in Der Neue Pauly (Kowalzig 2000). Artemis and Orthia were connected from earliest times.




gratia, after Bowra 1934, 4I. Cf. Carter 1988, 92-3.

13 $C f$. Vernant 1984, 22: 'le jeune occupe donc, entre l'Hilote et le citoyen de plein droit, une position intermédiaire. Il n'incarne pas le "sauvage".'


merely an actor; the other attestation (Plutarch, Agesilaos 21.4) glosses the term as $\mu$ înos. Di Clemente 2008 , I84 connects them explicitly.
} 



refers specifically to the wielding of a $\delta \varepsilon i \kappa \eta \lambda \mathrm{ov}$, an image or representation of some kind. ${ }^{6}$ Athenaeus goes on to compare other words for the same practice - $\varphi \alpha \lambda \lambda$ ó $\varphi$ opol, $\varphi \lambda v \dot{v} \alpha \varepsilon \varsigma$ - that clarify what sort of plays these were: depending in large measure on specific props, rather than on scripts (as Poetics 1449 a9-14) or plot. ${ }^{17}$

This is not to accord Athenaeus special status; quite simply, neither he nor any of the other ancient authors whom previous scholars have cited - Hesychius, Plutarch, Pollux, even Xenophon - can possibly have seen the Orthia masks, for they were buried intentionally many centuries before any of them wrote. The words of Athenaeus (and the others) are of value because they contain, perhaps, kernels of echoes of the practices at Orthia's sanctuary. Only Athenaeus' account corresponds to what we know of early Greek drama by comparison to other dramas (ancient and modern) and by the account of Aristotle (Poetics I448b22-4 and passim). Athenaeus is valuable for describing the first stage in the shift from a ritual drama to a non-ritual drama. ${ }^{18}$

Carter's central argument is that the masks of Orthia are the relics of a ritual drama depicting the hieros gamos of Orthia and her consort or 'the fiends who pursue and kill' him (Carter I987, 383). Yet there are no masks depicting Orthia herself (despite her frequent representation in other media: bronze, ivory (e.g. Fig. 6), terracotta); if any of the males depicts her consort (of whom there is only little evidence), he has no particular traits or characteristics; and the 'grimaces' of the masks are not aggressive but aggrieved. Rather, the abundance of masks and the total lack of representations of the god for whom they were worn (or dedicated) should fairly straightforwardly banish the idea of a ritual drama. Instead, there remain masks of various types and, at their finest, masks of unusual subtlety and expressivity.

Not all, of course, were expressive; the classes of 'heroes' and satyrs largely lack facial expression. But many called 'old women' or 'caricatures' and 'grotesques' - categories not without problems - are emotionally expressive, setting them quite apart from contemporary surviving objects. Classical (tragic) theatrical masks, or rather representations of them, are essentially apathic. ${ }^{19}$ There is a reason for this, viz. the varying emotions of a single character as seen in existing drama - though especially tragedy - and the use (generally) of a single mask for a character throughout a play. ${ }^{20}$ Strong facial expression prevents both the viewer from projecting his own assignations of emotion and the actor from making subtle physical changes that can affect the mask's appearance, as practiced in Noh theatre. ${ }^{21}$

Let us look again at Fig. I. Dickins labels this a caricature, presumably his type ii.b (Caricatures of 'Old Women'), though he was hesitant about the assignation of sex. ${ }^{22}$ Perhaps not a beautiful face, the only feature that might separate it from an entirely naturalistic rendering is the

I5 As does Plutarch's recounting of Lycurgus making a dedication to deified Laughter (Гé $\lambda \omega \varsigma)$, Lycurgus 25.2; on Spartan laughter see David I989 (masks: II-I2).

I6 $C f$. Herodotus 2.I7I.I: $\tau \grave{\alpha} \delta \varepsilon i ́ \kappa \eta \lambda \alpha \tau \hat{\omega} v \pi \alpha \theta \dot{\varepsilon} \omega v \alpha \hat{v} \tau 0 \hat{v}$, 'enactments of [Osiris'] sufferings'.

17 Leprohon 2007, 274-85 discusses Egyptian ritual 'scripts', largely stage directions and basic dialogue, e.g. the 'Ramesseum dramatic papyrus' (P.Ramesseum B, London BM 1929.60-I.4.2), which provides a script for the confrontation of Seth and Horus.

I8 Nielsen (2002, I2) defines ritual drama as 'dramatic performance with a plot taken from the myth of the god in whose honour it was enacted as a ritual during the festive liturgy'.

I9 Wiles 2000, I48; e.g. Agora P II8Io; cf. Boston MFA 98.883.

20 Meineck 20I I, I43 re the watchman's speech in Agamemnon: 'How then can a watchman's mask like those on the Pronomos vase, with a solid surface and fixed expression, project all these emotional states in a such a short space of time?'

${ }^{21}$ The 2000 study of Lyons et al., 'The Noh mask effect: Vertical viewpoint dependence of facial expression perception', demonstrates how the angle of tilt can profoundly affect the perceived emotion - and that the emotion perceived is culturally conditioned (in this experiment, varying between British and Japanese). This tilting is embedded in the theory and training of Noh performance (Lyons et al. 2000, 2244).

22 Sex assignation has been tentative since the masks' discovery. It is of note that the catalogue of (Classical) old men's masks in Rusten (20I I, 426) does not feature wrinkled examples - rather, old men were characterised by white hair or other features; old women's masks are wrinkled, as Ploutos I050-I. 




Fig. 6. Ivory figurines representing xoanon of Orthia. From the sanctuary of Artemis Orthia in Laconia. 700-600 BCE. Photograph: DAI (Neg. D-DAI-ATH-I975-07I2A).

wrinkling beside the mouth. The wrinkles are not particularly deep or broad (unlike other masks' wrinkles) - though if the carving is too subtle or shallow, the mask will be less discernible, especially in low light or at a distance - but fade and thin as they move away from the mouth. Compare a Japanese Noh mask of the 'Kojo' type ('old man', Fig. 7), which is similar in its expression and 




Fig. 7. Wood-and-hair Noh mask of the 'Kojo' type. Height: I9.I cm; I9th century CE. New York, Metropolitan Museum of Art 25.60.38. Photograph: Metropolitan Museum of Art, Rogers Fund, I925 <www.metmuseum.org>.

uses wrinkles in much the same way. ${ }^{23}$ Not all the masks' wrinkles are so closely connected to the movement of facial features, ${ }^{24}$ but the wrinkles serve to enhance expression by shadows' underscoring motion. To call a heavily wrinkled face a 'caricature' of an old face ignores the communicative purpose of a mask.

The expression of the mask illustrated in Fig. I is characterised by the opened and downturned mouth. The single tooth indicates old age. The muscle most active in this expression, the depressor anguli oris, the muscle lowering the corner of the mouth, is visibly contracted, creating a strong distension over which the wrinkles bend. Its action causes the lower lip to appear horizontal when viewed frontally and to curve back in profile; and the upper lip curves downward frontally and back in profile - a physiological accuracy not seen again until the Parthenon (e.g. London BM GR I845.5-I3.I).

In the upper portion of the fragment, two features are notable. One is the flaring of the right nostril, which is a companion muscular movement for strong contractions of the depressor anguli oris. More deliberate is the distension of the upper cheek that is the result of the contraction of the orbicularis oculi, the muscle surrounding the eye, which makes the eyes squint and brings the cheeks and brow closer together. If this was indeed the motion of the upper part of the complete mask, then the expression as a whole is of fear or pain. ${ }^{25}$ 
The greater part of the study of masking is devoted to tragic masks, which were largely expressionless; what of the expressive masks? Wiles writes:

The principles of the expressive mask are directly relevant to comedy, where distortions of the face encourage the actor to develop distorted patterns of movement, and it is a general truth that masks determine how the body will move. ${ }^{26}$

This depends, of course, on what is meant by 'distortions': the mask of a 'crétin', with his bronchocele and mangled face; ${ }^{27}$ or simply a face altered, perhaps violently, from its neutral state by emotion? Presumably it is the latter, in which case the pejorative connotations of the word must be ignored. Since the sanctuary lacked a theatre at this period, one type of distortion to rule out is optical; the strong incline of a cavea produces an angled aspect - stronger higher that literally shapes perception (see above, n. 2I). Strong facial expression must belong to the permanent characteristics of the masks (Gombrich's $p$ ), since the ways of rendering the expressions are inconsistent and various $(m) .{ }^{28}$ It is difficult, perhaps, to associate expressions of negative emotions - fear, pain, distress - with comedy or satire or farce; ${ }^{29}$ perhaps more difficult still to see what such a drama would have to do with the worship of Orthia.

With so many theories of Orthia's nature and role, it is little surprise that scholars have sought such far-flung explanations for the masks. Orthia has been variously described as a vegetation goddess, a male fertility goddess, a female fertility goddess, a livestock fertility goddess, a child-


childhood to adulthood. ${ }^{\circ}$ Association with Artemis yields several other familiar roles - and some unfamiliar. ${ }^{31}$ Fertility is the realm most often associated with Orthia, but this seems to be the collective fate of gods (especially goddesses) about whom little is known. The pattern exposes a rift in scholarship (long-standing if the accounts of ancient authors be considered) of the Orthia cult, viz. that some - Rose, ${ }^{32}$ Calame (1986), Frontisi-Ducroux, Parker, Vernant on the evidence of Hesychius, Pausanias, Plutarch (Lycurgus I8.I; [Plutarch] Apophthegmata Laconica 239C) and Xenophon - consider it a (male) ephebe-initiation cult, and others Calame (1977), Carter and Themelis (writing specifically of Messenian Orthia) on the evidence of Alcman,33 Plutarch (Theseus 3I.2) and Pollux - consider it a female cult, one in which Helen and the girl-choruses of Alcman might take part. Surely these ought to be exclusive functions, or at least to operate at different times (of the year?), since one of the near-universal characteristics of initiation cults is the separation of the sexes. ${ }^{34}$ If she served both functions, it ought to have the effect of weakening the association with either.

The origins of Orthia herself are somewhat clearer: she is a Dorian goddess, not found in any Mycenaean texts, who was worshipped elsewhere and eventually became associated, though never

26 Wiles 2000, I49 and 2008, 38I: '[comic] masks may transform the mental state of the wearer as much as the mental state of the spectator', specifically expressive masks.

27 Bosanquet I906, 342: 'an extraordinary piece of realistic modelling; the distorted mouth and cheeks and the goître on the neck are accurately observed' (emphasis mine).

28 E.g. Dawkins I929, pls. XLVII and XLIX.

29 Carter 1987, for instance, does not countenance comedy but classes them in the performance of part of the story of the god (like the Ramesseum dramatic papyrus; see above, n. I7): 'the grimacing masks, then, may have represented the fiends who pursue and kill Ortheia's lover'.

30 Vegetation: Dawkins I929, 402; male fertility: RE s.v. 'Orthia'; female fertility: Carter I987, 379; livestock


Dawkins I929, 403; transition: Vernant 1984, I7, Calame I986, I34. For a summary, see Bouvrie 2009, I53-8.

3I E.g. Di Clemente 2008, I85: 'Artemide sembra essere un vero e proprio alter ego della figura di Dioniso'.

32 H.W. Rose was responsible for describing the cult in Dawkins I929.

33 Page I95I, 7I-82 discusses the textual issues of the Partheneion and concludes (82): 'if Ortheia be not the goddess in question, there is not sufficient evidence to prove, or even to suggest, any other identification.' One might circumvent the whole issue by calling ö $\rho \rho \rho \curlywedge \alpha$ a deliberate verbal echo.

34 Calame I977, I.28Iff. tries to reconcile the two. Pindar, Olympian 3.5I-2 (composed c.476) records that a


location is given variously by the scholiasts). 
quite identified, with Artemis. The cult statue was a small wooden pillar-like frontal representation of the Orthia. 35 The cult of Artemis Orthia at Messene represents a later stage of development, with most of the trappings of Artemis; ${ }^{36}$ it was an essentially female cult, with female priests and a marked concern with childbirth. It is difficult to reconcile this with the cult of Orthia at Sparta in the Classical period being 'a male initiation cult', 37 though only thirty miles distant.

Of Spartan Orthia's nature one thing is certain: it was not stable over the course of her worship. Gorgoneia and representations of the potnia theron cease; the masks are made over perhaps 150 years of her ten-century worship, records of the contests of endurance (perhaps equivalent to the scourging of boys described in texts) exist only from the end of the fourth century, her association with Artemis grows more prominent over time. What persists is the location of the cult, just outside of Sparta on the west bank of the Eurotas river. As a suburban sanctuary, it enjoyed easy access from city-dwellers, and its location in the ancient swamp called Limnai shaped its character. ${ }^{38}$

Bouvrie (2009) asks whether Orthia is to be classed as a goddess of nature or of culture but does not consider whether she is both. Dionysos is god of both, and his connexion to drama in Athens is the index of that duality, as Aristotle articulates: as improvised drama migrates from country to town, its components become genres and diverge, and what is felt to be lost from the narrowing of one gives rise to others. The masks of Orthia are various, but most scholars focus on the grotesques, the caricatures, and the old women, yet exclude the male, the young, the 'portraits', even the satyrs. Their burial together makes clear that the masks were used together and were somehow in dialogue, yet few theories of their use account for the whole range. This must, at any rate, be a criterion of future theories.

\section{CONCLUSIONS}

Analysis of the material and technique of the terracotta masks shows that they vary in manufacture: fabric, size, thickness, tooling, piercing and polychromy are inconsistent. Taken with the masks' inhumation together, this supports two theories. The first is that the terracotta masks were not worn; since most could not physically be worn, those that could were in fact not. This tallies with the difficulty in wearing clay masks for any kind of performance that includes vigorous movement, to say nothing of dance, as demonstrated by the Egyptian painting of a man in an Anubis mask steered by an unmasked aid (above, n. 7). What follows naturally from this is the second theory: that the masks refer in various ways to performance masks made probably of linen, but possibly of wood or other light and manipulable materials, posited by the masks' excavators and widely accepted.

The reference was not direct, since the variations in appearance depend on the technique of working terracotta. Linen is manipulable in three dimensions but not so infinitely as clay, and its effect would have depended more on silhouette and two-dimensional decoration. Wood can be

35 Assumed to be reflected in the bone figurines of a long-necked female with horizontal striations to her hair and a polos (e.g. Fig. 6). Cf. 'Mantiklos', the bronze statuette from Boeotia, now in Boston (MFA 03.997), whose striated tresses elongate his neck.




II5) tacitly accepts. The xoanon was not only at Sparta but also at other cult sites (Themelis 2003, I22); Themelis also sketches the annual celebration of the goddess, and includes 'dramatic performances, including dances around the xoanon and the altar'.

37 Bouvrie 2009, I74; p. I59 claims a "notable decline in "female" votives in the Spartan sanctuary during the 6th century'. It is not at all clear what these would be: ivory combs need hardly be dedications from women; any 'female' object could be just as well explained by the goddess's sex as by the dedicant's. Rothwell (2007, I8) overstates: 'the cult of Artemis Orthia was organized for ephebes'.

${ }^{38}$ As Pausanias 3.16.7, though cf. Strabo 8.5.I: the land was once marshy but is no more (even at the time of the construction of even the earliest temple); Strabo (loc. cit.) claims that the temple there belonged to Dionysos - due to the theatricality of the cult? 
carved into like clay, but is not as freely manipulable and cannot readily be added to (as the ridges of the mask illustrated in Fig. I were added above the smooth surface of the mask). The makers of the clay masks must have taken some liberties in the execution of these durable dedications.

Our attention must then move to the perished originals: what did they look like and how were they used? To the first question we encounter the problem, as posed by Gombrich (see above), of isolating the permanent characteristics $(p)$ (those that belonged to the linen [vel sim.] masks as a class) from the mobile characteristics $(m)$ (the variations among the linen masks as well as in the translation of linen into clay), given that we see only their product $(p m)$. I propose the following list of $(p)$ :

(I) Covering only the front of the face

(2) Plastic, i.e. modelled in three dimensions

(3) Pierced at eyes (perhaps wider than later masks) 39 and mouth

(4) Painted, with special prominence given to eyes and mouth

(5) Divided into types by facial structure, expression and decoration (both non-anatomical features, such as spirals, and anatomical features, such as wrinkles)

Characteristic (5) allows for the expressiveness so prominent in the masks labelled by Dickins as caricatures, old women and grotesques. Whereas Classical and later tragic masks serve primarily to identify role - slave, matron, ephebe - comic masks can portray nature (Aristotle's $\hat{\eta} \theta 0 \varsigma$ ), and thereby influence the movement of the actor (see above). Not all classes of masks from Orthia contain expressive examples - e.g. the 'youths' and 'warriors' - from which we may conclude either that they were part of a different type of drama, or that there was a single theatrical form in which there were 'foils' or 'straight men', as we find in satyr drama, e.g. Odysseus in Euripides' Cyclops. $4^{\circ}$

What might this Orthian humorous drama - one that seems to have prominently featured old women expressing painful emotions - look like?4I A good comparison, contemporary with the middle of the series of masks (first quarter of the fifth century), is the scene depicted on the Beldam Painter's name vase (Fig. 8): five satyrs surround a woman (Lamia?) lashed to a palm tree and torture her. $4^{2}$ The viewer is not asked to overlay a plot, but simply to regard the spectacle. There is little doubt that humour is intended, given the exaggerations of the woman's physique (Halm-Tisserant 1989, 75), to say nothing of the mere presence of satyrs, who, when scripted, subvert expectations about proper behaviour. Halm-Tisserant (1989, 79) proposes that:

notre image laisse supposer que des anecdotes populaires, qui alimenteront par la suite le théâtre, circulaient dans les ateliers dès le début du Ve siècle, ou plus tôt.

The violent humour of the Lamia vase depends on her exaggerated ('distorted', to use Wiles's term) facial expression and body posture, which belong not to (Athenian) comedy ${ }^{43}$ but to farce or mime, as do the masks of Orthia.

The claim made in the title of this essay - that the masks of Orthia have something to do with the origins of drama - required a review of a broad range of sources and scholarship. Many of the scholarly treatments partially disagree with their forebears. A typical example is Jameson's

\footnotetext{
39 Meineck 20II, I39: 'nearly all of the fifth-century representations of masks indicate prominent sclerae: this strongly suggests that mask eye sockets were filled in, with only a small hole for viewing representing the pupil and iris'. All surviving eye-holes of Orthia masks are quite large, corresponding to the eyeball.

40 E.g. vv. 175-82: Odysseus speaks loftily of his time at Troy, and the satyr chorus asks whether the Greek captains took turns bedding her, as E.P. Coleridge renders, 'for she likes variety in husbands'.



42 Athens NM II 29; Paralipomena 292. Halm-Tisserant $(1989,76)$ points out the incised penis that others ignore, but this does not affect the rest of the body.

43 Cf. Aristophanes, Thesmophoriazusai 1002-135: Andromeda bound.
} 




Fig. 8. Black-figure lekythos attributed to the Beldam Painter (name vase). Found in Eretria (Euboea); c.500 BCE. Photograph: DAI (Neg. Hermann Wagner D-DAI-ATH-I929-I229A).

account (1990, 217) of the gorgoneion, in which he argues for the non-Phoenician origin of Orthia but otherwise accepts the other elements of Carter's argument. The literary parallels held up by the British excavators have caught the imagination of French scholars in particular, with their Frazerian descriptions of bloody ephebe-initiation, but evidence for these practices only begins several centuries after the masks. Scraping away the barnacles of anthropology and structuralism and orientalism, we are left with a wide array of masks of various manufacture that point to a broad, sophisticated range of dramatic practices. Most of the masks are inexpressive, merely types such as gorgons and bearded men - but some show the nascent interest in accurate facial expression, and the comic potential of showing a character's nature as well as his $\hat{\eta} \theta$ os.

It is difficult to agree with Nielsen $(2002,88)$ that the origin of drama in Greece is to be located at the sanctuary of Orthia at Sparta, but the masks seem to stand at the beginning of the shift from a purely ritual drama to a drama in which a broad range of masks was marshalled. The drama was rapidly evolving, as the end of series of gorgon and satyr masks indicates. The masks are not unique, though no other place has produced the same breadth and volume as Sparta; Samos, ${ }^{44}$

44 Figured in Boehlau I898, pl. XIII I, I $a$. 
Cyprus (as Fig. 5), Thera and Tiryns ${ }^{45}$ have all yielded isolated examples, and may well have had dramatic cultures as did the Orthia sanctuary at Sparta, but only the votive practices there have given evidence of the breadth of masks needed to posit a rich and vibrant drama. Wiles has posited a direct path from the sanctuary of Orthia to the theatres of Athens; ${ }^{46}$ this is obviously seductive, but we must remember that the survival of the masks at Orthia is due to the collocation of a dramatic practice as well as a votive practice. Still, the richness of the masks cannot have been rivalled in many other places.

The masks of Orthia have a magnetic pull, one whose effect can be seen on those who first excavated them and on those who have sought to explain them since. Scholars' passing over of the warriors and the satyrs is evidence of the appeal of the contorted, expressive, furrowed, toothless old faces. The British excavators were disgusted by them even as they were fascinated by them. So too, perhaps, were the worshippers at the sanctuary of Orthia. The masks are mirrors of human imperfection; what better origin of theatre could there be?

\section{ACKNOWLEDGEMENTS}

I wish to thank the department of Greek and Roman antiquities at the British Museum, and particularly Dr Fitton, its Keeper, for granting access to the objects in their collection.

jonahlrosenberg@gmail.com

\section{REFERENCES}

\author{
Abbreviated titles \\ $I G$ \\ Inscriptiones Graecae \\ (Berlin, I903-). \\ $L S \mathcal{F}$ \\ Liddell, H.G., Scott, R. and Jones, H.S. \\ 1940. A Greek-English Lexicon, 9th edn \\ (Oxford). \\ Paralipomena Beazley, J.D. (I97I). Paralipomena: \\ Additions to Attic Black-figure Vase \\ Painters and Attic Red-figure Vase \\ Painters (Oxford). \\ P.Ramesseum Gardiner, A.H. (1955). The Ramesseum \\ Papyri (Oxford). \\ $R E$
}

SEG

\author{
Supplementum Epigraphicum Graecum \\ (Leiden, I962-).
}

\section{Published Sources}

Boardman, J. I963. 'Artemis Orthia and chronology', Annual of the British School at Athens 58, I-7.

Boehlau, J. I898. Aus ionischen und italischen Nekropolen, Ausgrabungen und Untersuchungen zur Geschichte der nachmykenischen griechischen Kunst (Leipzig).

Bosanquet, R.C. 1906. 'The cult of Orthia as illustrated by the finds', Annual of the British School at Athens I2, 33I-43.

Bosanquet, R.C., Wace, A.J.B., Dickins, G., Dawkins, R.M. and Tillyard, H.J.W. I906. 'Laconia: II. Excavations at Sparta, 1906', Annual of the British School at Athens 12, 277-479.

Bouvrie, S. des 2009. 'Artemis Ortheia. A goddess of nature or a goddess of culture?', Acta Hyperborea I2, I53-90.

Bowra, C.M. I934. 'The occasion of Alcman's Partheneion', Classical Quarterly 28, 35-44.

Calame, C. 1977. Les choeurs de jeunes filles en Grèce archaïque (Rome).

\footnotetext{
45 As described in Pipili 2006, cat. 53 (p. 140). Masks 'from another Spartan sanctuary' are claimed to have emerged recently.

46 Wiles 2007, 214: the masks form 'part of the only Greek ceremony we know that could in the course of the sixth century have inspired Athenian use of performance masks'. This requires an explanation of the mechanism of influence: were foreigners allowed? How do Orthia and Dionysos relate? How early was Orthia introduced to Athens? To this last, at least, there is the evidence of $I G \mathrm{I}^{3} \mathrm{I083}$, dated $c .420$ and found on Mount Hymettos, a horos-stone of the hieron of Artemis Orthosia - a terminus ante quem.
} 
Calame, C. I986. 'Facing Otherness: The tragic mask in Ancient Greece', Fournal of the History of Religions 26, I25-42.

Carter, J.B. I987. 'The masks of Ortheia', American Fournal of Archaeology 91, 355-83.

Carter, J.B. I988. 'Masks and poetry in early Sparta', in Hägg, R., Marinatos, N. and Nordquist, G.C. (eds.), Early Greek Cult Practice (Stockholm), 89-98.

Catling, H.W. I977. 'Excavations at the Menelaion, I976-1977', Lakonikai Spoudai 3, 408-16.

David, E. I989. 'Laughter in Spartan society', in Powell, A. (ed.), Classical Sparta: Techniques behind Her Success (London), I-25.

Dawkins, R.M. (ed.) 1929. The Sanctuary of Artemis Orthia at Sparta (London).

Dawkins, R.M., Wace, A.J.B., Droop, J.P., Dickins, G., Tillyard, H.J.W., Woodward, A.M. and Tod, M.N. 1906/7. 'Laconia: I. Excavations at Sparta, 1907', Annual of the British School at Athens 13, I-2 I8.

Di Clemente, P. 2008. 'Sparta ridente. Le maschere di Orthia e le origine della farsa dorica', in Menozzi, O., Di Marzio, M.L and Fossataro, D. (eds.), SOMA 2005 (Oxford), I83-5.

Gombrich, E.H. 1982. The Image and the Eye (Oxford).

Halm-Tisserant, M. I989. 'Folklore et superstition en Grèce classique: Lamia Torturée?', Kernos 2, 67-82.

Jameson, M.H. I990. 'Perseus, the hero of Mykenai', in Hägg, R. and Nordquist, G.C. (eds.), Celebrations of Death and Divinity in the Bronze Age Argolid (Stockholm), 213-23.

Kilian, I. I978. 'Weihungen an Eileithyia und Artemis Orthia', Zeitschrift für Papyrologie und Epigraphik 31, 219-22.

Kowalzig, B. 2000. 'Orth(e)ia', in Cancik, H. and Scheider, H. (eds.), Der Neue Pauly. Enzyklopädie der Antike (Stuttgart and Weimar), vol. 9, cols 7I-3.
Leprohon, R.J. 2007. 'Ritual drama in Ancient Egypt', in Csapo, E. and Miller, M.C. (eds.), The Origins of Theater in Ancient Greece and Beyond (Cambridge), 259-92.

Lyons, M.J., Campbell, R., Plante, A., Coleman, M. and Kamachi, M. 2000. 'The Noh mask effect: Vertical viewpoint dependence of facial expression perception', Proceedings of the Royal Society of London, Series B 267, 2239-45.

Meineck, P. 20II. 'The neuroscience of the tragic mask', Arion I9, II3-58.

Nielsen, I. 2002. Cultic Theatres and Ritual Drama (Aarhus).

Nilsson, M.P. I955. Geschichte der griechischen Religion I, and edn (Munich).

Page, D.L. I95I. Alcman. The Partheneion (Oxford).

Parker, R. 1989. 'Spartan Religion', in Powell, A. (ed.), Classical Sparta: Techniques behind Her Success (London), I42-72.

Pipili, M. 2006. 'Laconian Pottery', in Kaltsas, N. (ed.), Athens-Sparta (New York), I23-I4I.

Rothwell, K.S. Jr (2007). Nature, Culture, and the Origins of Greek Comedy (Cambridge).

Rusten, J. 20II. The Birth of Comedy (Baltimore).

Themelis, P.G. (trans. Hardy, D.) 2003. Ancient Messene (Athens).

Vernant, J.-P. I984. 'Une divinité des marges: Artémis Orthia', in Breglia Pulci Doria, L., Ellinger, P., Frontisi-Ducroux, F., Lepore, E., Montepaone, C. and Vernant, J.-P. (eds.), Recherches sur les cultes grecs et l'occident, 2 (Naples), 13-27.

Wiles, D. I99I. The Masks of Menander (Cambridge).

Wiles, D. 2000. Greek Theatre Performance (Cambridge).

Wiles, D. 2007. Mask and Performance in Greek Tragedy (Cambridge)

Wiles, D. 2008. 'The poetics of the mask in Old Comedy', in Revermann, M. and Wilson, P. (eds.), Performance, Iconography, Reception: Studies in Honour of Oliver Taplin (Oxford), 374-92.



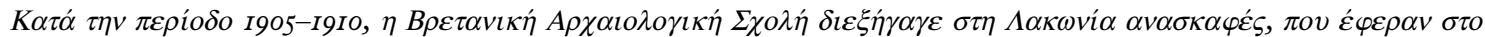

















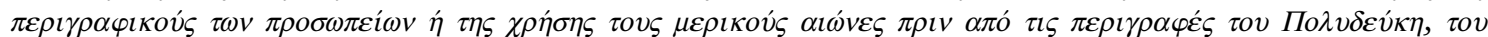





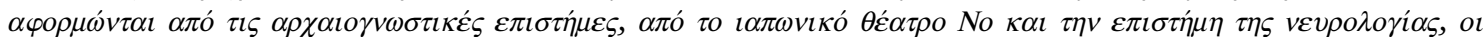





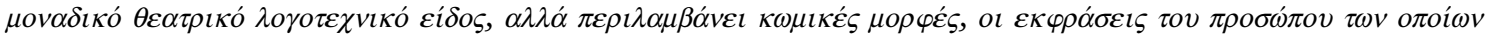







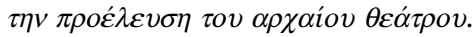

